\title{
Expression of the WT1 gene-KTS domain isoforms suppresses the invasive ability of human lung squamous cell carcinoma cells
}

\author{
SHOGO MORIYA ${ }^{1,2,3}$, MASAKI TAKIGUCHI ${ }^{2}$ and NAOHIKO SEKI ${ }^{1}$ \\ Departments of ${ }^{1}$ Functional Genomics and ${ }^{2}$ Biochemistry and Genetics, Chiba University Graduate School \\ of Medicine; ${ }^{3}$ Research and Development Center, Nisshinbo Industries, Inc., Chiba, Japan
}

Received March 12, 2007; Accepted May 2, 2007

\begin{abstract}
Although the WT1 gene was originally isolated as a tumor suppressor gene from Wilms' tumor, oncogenic roles for WT1 have been reported in several tumors. Here, we present new findings of high levels of WT1 expression associated with the suppression of lymph node metastasis in patients with human lung squamous cell carcinoma (SCC). We investigated the effect of down-regulated WT1 gene expression on the invasive phenotype of the SCC cell line RERF-LC-AI. Invasive ability was enhanced in WT1-specific siRNA-transfected cells, and a WT1 target gene $p 21^{\text {Wafl/Cipl }}$ was isolated by comprehensive gene expression analysis. As several isoforms are produced from the WT1 gene, we isolated eight major WT1 isoforms from a cDNA library and cloned each variant into an expression vector. Luciferase reporter assays revealed that $p 21^{\text {Wafl/Cipl }}$ expression was enhanced only by the WT1 cDNA variants that included a three-amino acid deletion (-KTS). Our results suggested that the -KTS-containing variants of WT1 are directly involved in the regulation of $p 21^{\text {Wafl/Cipl }}$ expression and the subsequent suppression of lymph node metastasis in human lung squamous cell carcinoma.
\end{abstract}

\section{Introduction}

The Wilms' tumor gene (WT1) was originally isolated as the gene responsible for the child neoplasm Wilms' tumor through its deletion in a subset of patients. The WT1 gene maps to chromosomal band $11 \mathrm{p} 13$, spans approximately $50 \mathrm{~kb}$, and is comprised of ten exons. The WT1 protein is a member of the zinc finger-type family of transcription factors and is responsible for the controlled expression of a variety of proliferation- and differentiation-associated target genes (1).

The role of WT1 as a tumor suppressor gene has been established by studies that demonstrated inactivating point mutations and homozygous deletions in Wilms' tumor tissues

Correspondence to: Dr Naohiko Seki, Department of Functional Genomics, Chiba University Graduate School of Medicine, 1-8-1 Inohana, Chuo, Chiba 260-8670, Japan

E-mail: naoseki@faculty.chiba-u.jp

Key words: WT1, -KTS isoform, invasion, $\mathrm{p} 21^{\mathrm{Waf} 1 / \mathrm{Cip} 1}$, lung squamous cell carcinoma
(1). However, recent studies have shown that WT1 may also have oncogenic functions. In human myelocytic leukemia, acute lymphocytic leukemia, and chronic myelocytic leukemia, high levels of WT1 expression have frequently been found and associated with the development of more primitive and refractory forms of disease (2-4). Furthermore, WT1 overexpression has been reported in several human solid tumor specimens including ovarian cancer $(5,6)$, breast cancer $(7,8)$, lung cancer $(9,10)$, esophageal cancer $(11)$, colorectal adenocarcinoma (12), head and neck squamous cell carcinoma (13), and osteogenic sarcoma (14).

Exons 5 and 9 of WT1 are alternatively spliced, giving rise to four different splice isoforms. The inclusion of exon 5 inserts 17 amino acids, while the usage of an alternate splice donor site at the end of exon 9 results in the incorporation of three additional amino acids, lysine, threonine and serine (KTS). In addition to WT1 isoforms translated from the authentic initiator AUG, smaller WT1 isoforms have been described, through the usage of an internal translation initiation site at the in-frame AUG 127 codon downstream of the initiator AUG, generating truncated WT1 isoforms (15). Furthermore, a short transcript that lacks 147 amino acids at the N-terminus has also been reported (16). Although all the isoforms are expressed in primary human solid tumors and leukemia, the functions of the individual WT1 isoforms in human cancer cells remain unclear.

Recently, we demonstrated that WT1 expression correlated with lymph node metastasis in patients with lung adenocarcinoma (AD), and that patients that expressed WT1 showed significantly lower rates of disease-free survival compared with patients that did not express WT1. This tendency was reversed in patients with lung squamous cell carcinoma (SCC), whereby WT1 non-expression was correlated with lymph node metastasis and recurrence. In an effort to explore this phenomenon in patients with lung SCC, we examined the effect of expression of each of the WT1 isoforms on metastasis development in human lung SCC cell lines.

\section{Materials and methods}

Cell line and cell culture. The human lung SCC cell line RERF-LC-AI was obtained from the Riken cell bank and grown in Dulbecco's modified Eagle's medium (DMEM) supplemented with $10 \%$ fetal bovine serum in a humidified atmosphere containing $5 \% \mathrm{CO}_{2}$ at $37^{\circ} \mathrm{C}$. 
siRNA transfection. Control siRNA (negative control siRNA), WT1 siRNA (Hs_WT1_1), and p21 Waf1/Cip1 siRNA (Hs_CDKN1A_7) were obtained from Qiagen (Hilden, Germany). Transfection into RERF-LC-AI cells was performed using a final concentration of $5 \mathrm{nM}$ siRNA and HiPerFect transfection reagent (Qiagen).

RNA purification and preparation of cDNA. Total RNA was isolated from cells using Trizol (Invitrogen, Carlsbad, CA) according to the manufacturer's instructions, and $1 \mu \mathrm{g}$ aliquots of total RNA were converted into cDNA using oligo dT primers (Invitrogen) and SuperScript II reverse transcriptase (Invitrogen) according to the manufacturer's instructions.

Reverse transcription-polymerase chain reaction ( $R T-P C R)$. RT-PCR was performed in $20 \mu 1$ reaction mixtures containing $10 \mu 1$ HotStarTaq master mix (Qiagen), $0.5 \mu \mathrm{M}$ each forward and reverse primer, and $1 \mu \mathrm{l}$ cDNA. Sequences of the primers used were as follows: WT1 forward primer, 5'-GATAACCA CACAACGCCCATC-3', and reverse primer, 5'-CACACGT CGCACATCCTGAAT-3'; p21 $1^{\text {Waf1/Cipl }}$ forward primer, 5'-TA TGGGGCTGGGAGTAGTTG-3', and reverse primer, 5'-AG CCGAGAGAAAACAGTCCA-3'; ß-actin forward primer, 5'-GACAGGATGCAGAAGGAGATTACT-3', and reverse primer, 5'-TGATCCACATCTGCTGGAAGGT-3'. RT-PCR was performed using a GeneAmp 9700 (Applied Biosystems, Foster, CA) with conditions of activation at $95^{\circ} \mathrm{C}$ for $15 \mathrm{~min}$, followed by 35 cycles of denaturation at $94^{\circ} \mathrm{C}$ for $15 \mathrm{sec}$, annealing at $60^{\circ} \mathrm{C}$ for $30 \mathrm{sec}$ and extension at $72^{\circ} \mathrm{C}$ for $30 \mathrm{sec}$. For real-time RT-PCR analysis, the same primers and conditions were used except that the number of cycles was increased to 40 . Standard curves for quantitation were constructed from the results of simultaneous amplification of serial dilutions of cDNA from non-treated RERF-LC-AI cells, from which the expression level was defined as 1.0.

In vitro invasion assay. Following siRNA transfection, cells were incubated for $24 \mathrm{~h}$, harvested, counted, and dispersed in FBS-free DMEM, and $5 \times 10^{4}$ cells/well were added to inserts (upper chamber). Culture medium containing 10\% FBS as the chemotactic agent was added to the lower chamber. After $22 \mathrm{~h}$ incubation, non-invading cells were removed from upper filter surfaces and filters washed, fixed and stained using DiffQuick kit (Sysmex, Kobe, Japan). Four randomly selected x200 fields were photographed and invading cells counted.

Cell growth assay. Cells were seeded into six-well plates at a density of $0.5 \times 10^{4}$ cells/well and counted after $27,48,72$ and $94 \mathrm{~h}$ of incubation. Cell numbers were determined using a Coulter counter (Beckman Coulter, Fullerton, CA).

DNA microarray analysis. AceGene Human Oligo Chip 30K microarrays (DNA Chip Research Inc. \& Hitachi Software Engineering, Yokohama, Japan) containing a total of 30,336 spots corresponding to 29,640 independent genes (gene list available at http://bio.hitachi-sk.co.jp/acegene/) were used for expression profiling. Total RNA $(1 \mu \mathrm{g})$ was used for RNA amplification. Amino allyl-labeled antisense RNA (aRNA) was prepared using the Amino Allyl MessageAmp aRNA kit (Ambion, Austin, TX), and amino allyl-modified aRNA was then labeled with $\mathrm{Cy} 5$ or $\mathrm{Cy} 3$. Of labeled aRNA, $5 \mu \mathrm{g}$ was used for each hybridization experiment. Probe purification, hybridization, and washing steps were performed according to the manufacturer's instructions. DNA microarray analysis was repeated using a dye-swap. Arrays were scanned using the Packard GSI Lumonics ScanArray 4000 (Perkin Elmer, Boston, MA), and data analyzed by DNASISarray software (Hitachi Software Engineering, Yokohama, Japan), which converted the signal intensity of each spot into a text format.

Statistical analyses of DNA microarray data. Mean and standard deviations (SD) of background levels were calculated, and genes with intensities less than the mean + 2SD of background level were excluded from further analysis. Cy3/Cy5 ratios for all spots on the microarray were normalized by global normalization. Mean and SD of log2-ratios were calculated, and genes with expression levels of $\log 2$-ratios that varied more or less than the mean \pm 2 SD of all analyzed genes were subjected to further analysis.

WT1 cDNA gene cloning. WT1 cDNA was generated by RT-PCR using primers that contained KpnI and MluI sites (underlined) to facilitate cloning: short isoform forward primer, 5'-GGTACCATGTTTCCTAACGCGCCCTACCTGCCCAG$3^{\prime}$ and reverse primer, 5'-ACGCGTTTCCTTTTGAATAGAC TTTAATTGAGAGC-3', normal isoform forward primer, 5'GGTACCCAGCAAATGGGCTCCGAC-3'. Products were subcloned into the pCMVFL3 expression vector (Toyobo, Osaka, Japan).

Western blot analysis. Protein was extracted in lysis buffer [50 mM Tris pH 8.0, 1\% Triton-X, $450 \mathrm{mM} \mathrm{NaCl,} 100 \mu \mathrm{g} / \mathrm{ml}$ PMSF, $20 \mu \mathrm{l} / \mathrm{ml}$ Protease inhibitor cocktail (Sigma-Aldrich, St. Louis, MO)]. Whole cell lysates $(10 \mu \mathrm{g})$ were separated by electrophoresis in $10 \%$ tris-glycine SDS polyacrylamide gels and then transferred onto nitrocellulose membranes. After blocking in TBST (50 mM Tris pH 7.6, $150 \mathrm{mM} \mathrm{NaCl}$, and $0.1 \%$ Tween 20 ) plus $5 \%$ (wt/vol) nonfat milk, blots were incubated for $45 \mathrm{~min}$ at room temperature with primary antibodies, then incubated with HRP-conjugated secondary antibody, and finally visualized using ECL (GE Healthcare, Danbury, CT). Equivalent protein loading was evaluated using anti-WT1 (1:1000; Santa Cruz Biotechnology, Santa Cruz, CA) or anti $\beta$-actin (1:1000; Sigma-Aldrich) antibodies.

Construction of the reporter plasmid harboring the 5' p21 Wafl/Cipl promoter. The $p 21^{\text {Wafl/Cipl }}$ promoter $(-2317$ to +49 of the $p 21^{\text {Wafl/Cip } 1}$ proximal promoter region) was generated by PCR with primers containing NheI and HindIII sites (underlined) to facilitate cloning: forward primer, 5'-GCTA GCCCCAGGAACATGCTTGGGCAGCAG-3' and reverse primer, 5'-AAGCTTAGCTCCGGCTCCACAAGGA-3'. The p21 $1^{\text {Wafl/Cipl }}$ promoter fragment was subcloned into the luciferase reporter construct pGL3 (Promega, Madison, WI), and designated as pGL3-p21.

Luciferase reporter assays. Luciferase reporter assays were performed using the PicaGene Dual SeaPansy ${ }^{\mathrm{TM}}$ luminescence kit (Wako, Osaka, Japan). Of each of the pGL3-p21 reporter plasmid and the pCMVFL3 constructs expressing each WT1 isoform, $1 \mu \mathrm{g}$ was co-transfected by Lipofectamine 2000 
A

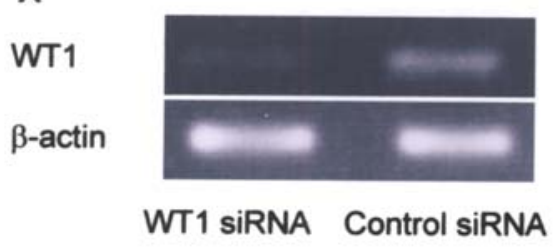

B

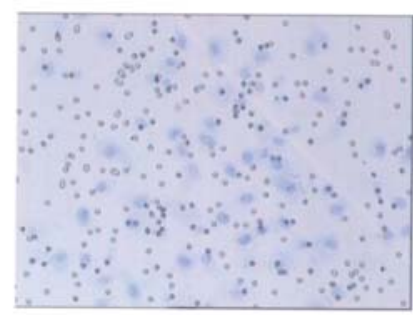

WT1 siRNA

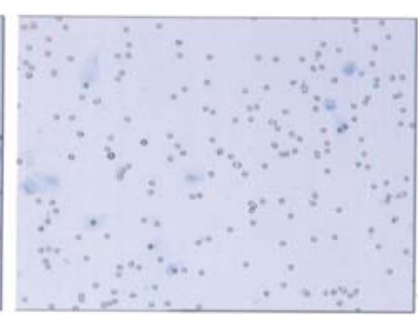

Control siRNA
C

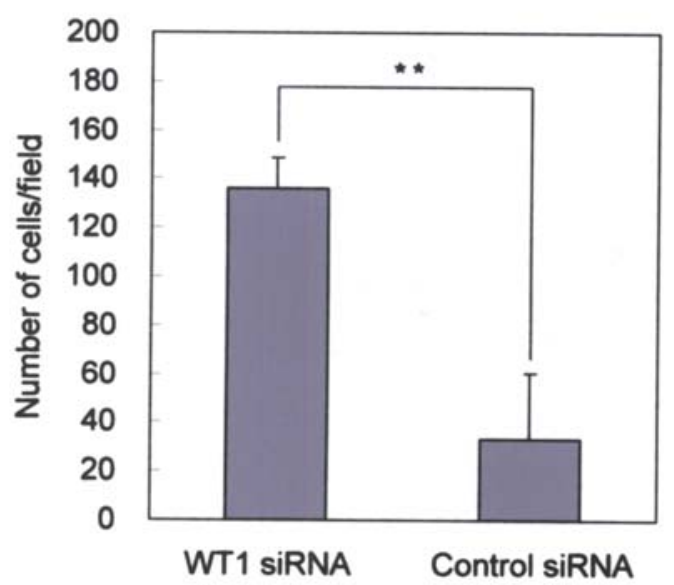

D

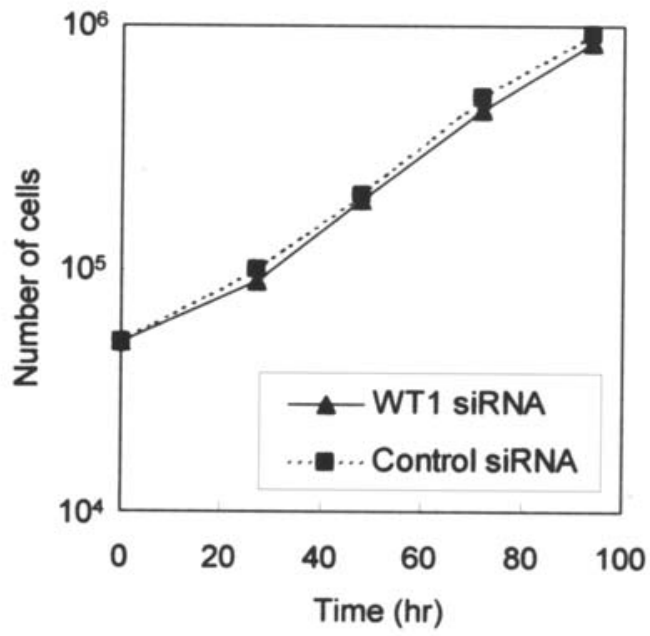

Figure 1. Effect of WT1-specific siRNA treatment on the invasiveness of RERF-LC-AI cells. (A) Down-regulation of WT1. Total RNA derived from RERFLC-AI cells transfected with WT1-specific siRNA (WT1 siRNA) or negative control siRNA (control siRNA) were subjected to RT-PCR. (B) Invasion into Matrigel. Diff-Quick staining showed the invasion of cells transfected with WT1 siRNA or control siRNA in an invasion assay. Cells were collected $24 \mathrm{~h}$ after transfection, dispersed in FBS-free DMEM, and added to the insert. After $22 \mathrm{~h}$, non-invading cells were removed from the upper filter surface and the filter washed, fixed and stained. (C) Quantification of invasiveness. WT1 siRNA-treatment of cells led to a significant increase in the number of invading cells compared with control siRNA-treated cells. ${ }^{* *} \mathrm{P}<0.01$. (D) Effect on RERF-LC-AI cell growth. Growth curves of cells transfected with WT1 siRNA or control siRNA showed no significant differences.

(Invitrogen). To monitor transfection efficiency, $10 \mathrm{ng} \mathrm{pRL}-$ CMV vector was co-transfected with each sample. After $48 \mathrm{~h}$, luciferase reporter activity was measured according to the manufacturer's instructions.

Statistical analysis. Experiments were repeated at least three times. Statistical analysis was performed using Student's t-test. Differences were considered significant at $\mathrm{P}<0.05$.

\section{Results}

Increased invasiveness of RERF-LC-AI cells following inhibition of WT1 expression. Effects of altered WT1 expression on invasion and cell growth were examined. Transfection of RERF-LC-AI lung SCC cells with WT1specific siRNA (WT1 siRNA) resulted in decreased levels of WT1 expression compared to cells transfected with negative control siRNA (control siRNA) (Fig. 1A). To assay for invasiveness, siRNA-treated cells were incubated in transwell plates coated with Matrigel for $22 \mathrm{~h}$ to allow cell invasion. WT1 siRNA-treated cells showed significant increases in invading cell numbers compared with control siRNA-treated cells $(\mathrm{P}<0.01)$ (Fig. 1B and C). WT1 siRNA treatment caused no significant changes in cell growth compared to the control siRNA treatment (Fig. 1D).

Expression analysis by microarray. As significant changes in invasiveness were observed in WT1 siRNA-treated cells (Fig. 2A), the effects of altered WT1 levels on patterns of gene expression were examined. Total RNA extracted from cells $24 \mathrm{~h}$ after WT1 siRNA treatment or control siRNA treatment was subjected to DNA microarray analysis, which was repeated using a dye-swap. Changes in gene expression were considered meaningful if expression levels varied by more or less than the mean $\pm 2 \mathrm{SD}$ over all analyzed genes for both dye configurations. By these criteria, 11 genes were up-regulated over the mean $+2 \mathrm{SD}$ (Table I), while 23 genes were down-regulated under the mean - 2SD (Table II). Cyclin-dependent kinase inhibitor $1 \mathrm{~A}\left(\mathrm{p} 21^{\text {Waf1/Cipl }}\right)$ was selected for further analysis, and down-regulation of $p 21^{\text {Wafl/Cipl }}$ expression in WT1 siRNA-treated cells was confirmed by real-time RT-PCR (Fig. 2B). 

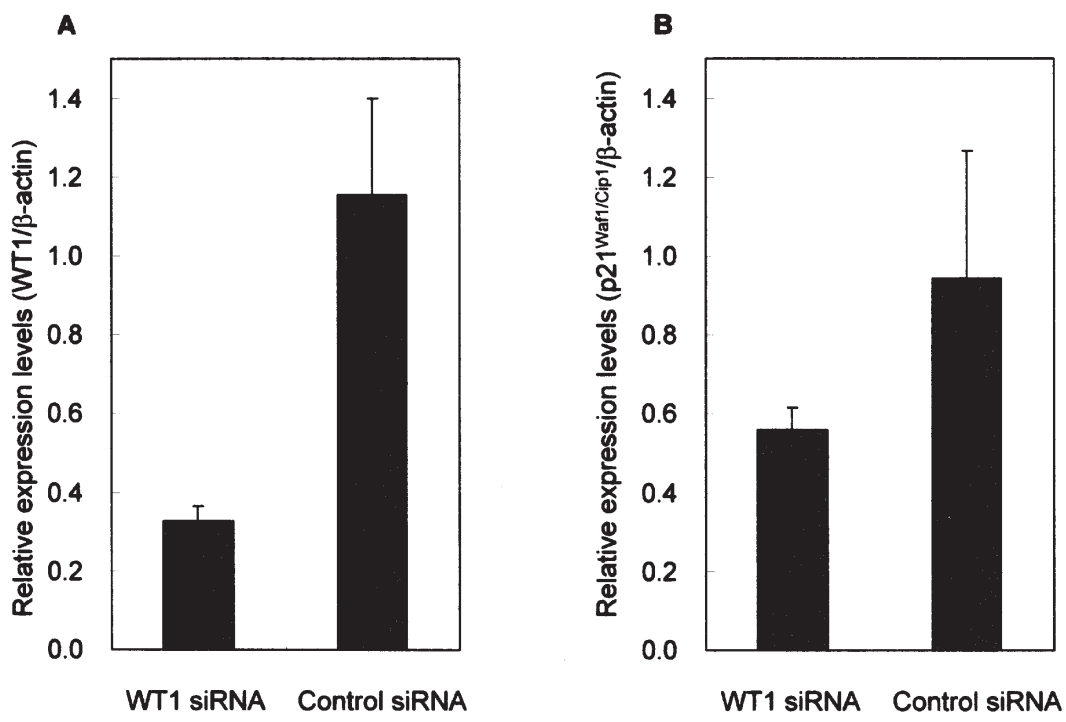

Figure 2. WT1 and $p 21^{\text {Wafl/Cipl }}$ expression in WT1-specific siRNA-transfected RERF-LC-AI cells. (A) WT1 expression was quantified by real-time RT-PCR in RERF-LC-AI cells transfected with WT1 siRNA or control siRNA as in Fig. 1. (B) $p 21^{\text {Wafl/Cipl }}$ expression. Down-regulation of $p 21^{\text {Wafl/Cipl }}$ in WT1 siRNAtransfected RERF-LC-AI cells was confirmed.

Table I. Genes up-regulated above the mean + 2SD in WT1 down-regulated cells.

\begin{tabular}{|c|c|c|c|c|c|c|}
\hline Gene name & Symbol & Accession no. & Gene ID & Location & Median & Function \\
\hline secretogranin III & SCG3 & NM_013243 & 29106 & $15 \mathrm{q} 21$ & 2.625 & Other \\
\hline hypothetical protein xp_051447; loc95256 & - & - & - & - & 2.133 & Unknown \\
\hline h4 histone family, member c & HIST1H4F & NM_003540 & 8361 & $6 \mathrm{p} 21.3$ & 1.912 & Other \\
\hline aspartate $\beta$-hydroxylase & ASPH & NM_004318 & 444 & $8 \mathrm{q} 12.1$ & 1.909 & $\begin{array}{c}\text { Signal } \\
\text { transduction }\end{array}$ \\
\hline tropomyosin 4 & TPM4 & NM_003290 & 7171 & $19 \mathrm{p} 13.1$ & 1.860 & $\begin{array}{l}\text { Cytoskeleton/cell } \\
\text { membrane-linked }\end{array}$ \\
\hline acetyl-Coenzyme A carboxylase $\alpha$ & ACACA & NM_198834 & 31 & $17 \mathrm{q} 21$ & 1.776 & Metabolism \\
\hline hypothetical protein xp_030958; loc90333 & - & - & - & - & 1.759 & Unknown \\
\hline hypothetical protein mgc5384; mgc5384 & - & - & - & - & 1.749 & Unknown \\
\hline $\begin{array}{l}\text { chorionic somatomammotropin hormone } 1 \\
\text { (placental lactogen) }\end{array}$ & CSH1 & NM_001317 & 1442 & $17 q 24.2$ & 1.722 & $\begin{array}{l}\text { Signal } \\
\text { transduction }\end{array}$ \\
\hline chromosome 11 open reading frame 16 & C11 orf16 & NM_020643 & 56673 & $11 \mathrm{p} 15.3$ & 1.637 & Unknown \\
\hline WD repeat domain $5 \mathrm{~B}$ & WDR5B & NM_019069 & 54554 & $3 q 21.1$ & 1.596 & $\begin{array}{c}\text { Signal } \\
\text { transduction }\end{array}$ \\
\hline
\end{tabular}

Increased invasiveness via inhibition of $p 21^{\text {Wafl/Cipl }}$ expression. To confirm the involvement of $\mathrm{p} 21^{\text {Waf1/Cip1 }}$ in invasion, p2 $1^{\text {Wafl/Cip } 1}$-specific siRNA (p21 Waf1/Cip1 siRNA)-transfected RERF-LC-AI cells were compared to control siRNA-treated cells in the invasion assay. Transfection with $\mathrm{p} 21^{\text {Wafl/Cip1 }}$ siRNA led to decreased $p 21^{\text {Wafl/Cipl }}$ expression levels (Fig. 3A), and significantly increased invading cell numbers compared with control siRNA-treated cells $(\mathrm{P}<0.01)$ (Fig. 3B and $\mathrm{C})$. No significant differences in cell growth were observed between the $\mathrm{p} 21^{\text {Waf } 1 / \text { Cip } 1}$ siRNA-treated and control siRNA-treated RERF-LC-AI cells (Fig. 3D).
Cloning of WT1 isoforms. To examine the effect on endogenous p21 $1^{\text {Wafl/Cipl }}$ expression in RERF-LC-AI cells after exposure to different WT1 isoforms, 8 WT1 isoform cDNA sequences (Fig. 4A) were cloned and sequence-confirmed. Each isoform was named according to a scheme whereby WT1 $17 \mathrm{AA}^{+} / \mathrm{KTS}^{+}$ or WT1s 17AA-/KTS- referred to 'WT1' as the translational start from the authentic initiator AUG, while 'WT1s' referred to translation from the downstream in-frame AUG 127 codon; ' $17 \mathrm{AA}^{+}$' indicated insertion of exon 5 ; ' $17 \mathrm{AA}^{\text {', }}$, deletion of exon 5; ' $\mathrm{KTS}^{+}$', insertion of KTS at the end of exon 9, and 'KTS', deletion of KTS. Each cDNA was inserted into the 
Table II. Genes down-regulated below the mean - 2SD in WT1 down-regulated cells.

\begin{tabular}{|c|c|c|c|c|c|c|}
\hline Gene name & Symbol & Accession no. & Gene ID & Location & Median & Function \\
\hline hairy and enhancer of split 1, (Drosophila) & HES1 & NM_005524 & 3280 & $3 q 28-q 29$ & 0.370 & $\begin{array}{l}\text { Transcription } \\
\text { and processing }\end{array}$ \\
\hline dj345p10.3 (3' end of a novel gene) & - & - & - & - & 0.437 & Unknown \\
\hline $\begin{array}{l}\text { v-abl Abelson murine leukemia viral oncogene } \\
\text { homolog } 2\end{array}$ & ABL2 & NM_005158 & 27 & $1 q 24-q 25$ & 0.440 & $\begin{array}{l}\text { Signal } \\
\text { transduction }\end{array}$ \\
\hline growth arrest and DNA-damage-inducible, $\alpha$ & GADD45A & NM_001924 & 1647 & $1 \mathrm{p} 31.2-\mathrm{p} 31.1$ & 0.469 & $\begin{array}{l}\text { Cell-cycle } \\
\text { regulation }\end{array}$ \\
\hline $\begin{array}{l}\text { UDP-N-acetyl- } \alpha-D \text {-galactosamine:polypeptide- } \\
\mathrm{N} \text { acetylgalactosaminyl-transferase } 14 \\
\text { (GalNAc-T14) }\end{array}$ & GALNT14 & NM_024572 & 79623 & $2 \mathrm{p} 23.1$ & 0.494 & Other \\
\hline chemokine (C-X-C motif) ligand 9 & CXCL9 & NM_002416 & 4283 & $4 q 21$ & 0.499 & $\begin{array}{l}\text { Signal } \\
\text { transduction }\end{array}$ \\
\hline MCF.2 cell line derived transforming sequence & MCF2 & NM_005369 & 4168 & $\mathrm{Xq} 27$ & 0.521 & $\begin{array}{l}\text { Signal } \\
\text { transduction }\end{array}$ \\
\hline neuronal PAS domain protein 3 & NPAS3 & NM_022123 & 64067 & $14 q 12-q 13$ & 0.541 & $\begin{array}{l}\text { Transcription } \\
\text { and processing }\end{array}$ \\
\hline polycystic kidney disease 2 -like 2 & PKD2L2 & NM_014386 & 27039 & $5 q 31$ & 0.542 & $\begin{array}{l}\text { Cytoskeleton/cell } \\
\text { membrane-linked }\end{array}$ \\
\hline fibroblast growth factor receptor substrate 2 & FRS2 & NM_001042555 & 10818 & $12 q 15$ & 0.548 & $\begin{array}{c}\text { Cell } \\
\text { differentiation }\end{array}$ \\
\hline spermidine/spermine N1-acetyltransferase & SAT & NM_002970 & 6303 & $\mathrm{Xp} 22.1$ & 0.560 & Metabolism \\
\hline tetraspanin 16 & TSPAN16 & NM_012466 & 26526 & $19 \mathrm{p} 13.2$ & 0.561 & $\begin{array}{l}\text { Cytoskeleton/cell } \\
\text { membrane-linked }\end{array}$ \\
\hline $\begin{array}{l}\text { cyclin-dependent kinase inhibitor } 1 \mathrm{~A} \\
\left(\mathrm{p} 21^{\text {Waf1/Cip1 }}\right)\end{array}$ & CDKN1A & NM_000389 & 1026 & $6 \mathrm{p} 21.2$ & 0.565 & $\begin{array}{l}\text { Cell-cycle } \\
\text { regulation }\end{array}$ \\
\hline hypothetical protein pro1097; pro1097 & - & - & - & - & 0.572 & Unknown \\
\hline $\begin{array}{l}\alpha-1,3-d-\text { mannoside } \beta-1,4-n- \\
\text { acetylglucosaminyltransferase iv-homologue }\end{array}$ & - & - & - & - & 0.576 & Unknown \\
\hline sodium channel, voltage-gated, type $\mathrm{X}, \alpha$ & SCN10A & NM_006514 & 6336 & 3 p22-p21 & 0.582 & $\begin{array}{l}\text { Cytoskeleton/cell } \\
\text { membrane-linked }\end{array}$ \\
\hline $\begin{array}{l}\text { protein kinase (cAMP-dependent, catalytic) } \\
\text { inhibitor } \alpha\end{array}$ & PKIA & NM_006823 & 5569 & $8 \mathrm{q} 21.11$ & 0.583 & $\begin{array}{l}\text { Signal } \\
\text { transduction }\end{array}$ \\
\hline hypothetical protein xp_043007; loc92132 & - & - & - & - & 0.584 & Unknown \\
\hline connective tissue growth factor & CTGF & NM_001901 & 1490 & $6 \mathrm{q} 23.1$ & 0.585 & $\begin{array}{l}\text { Cell adhesion/ } \\
\text { surface-linked }\end{array}$ \\
\hline $\begin{array}{l}\text { retinoic acid receptor responder } \\
\text { (tazarotene induced) } 1\end{array}$ & RARRES1 & NM_002888 & 5918 & $3 q 25.32$ & 0.605 & Cell proliferation \\
\hline armadillo repeat containing 4 & ARMC4 & NM_018076 & 55130 & 10p12.1-p11.23 & 0.607 & $\begin{array}{l}\text { Cytoskeleton/cell } \\
\text { membrane-linked }\end{array}$ \\
\hline G protein-coupled receptor 45 & GPR45 & NM_007227 & 11250 & 2q11.1-q12 & 0.613 & $\begin{array}{l}\text { Signal } \\
\text { transduction }\end{array}$ \\
\hline putative GR6 protein & C3orf 27 & NM_007354 & 23434 & $3 q 21$ & 0.636 & Unknown \\
\hline
\end{tabular}

pCMVFL3 expression vector, and resultant constructs transfected into RERF-LC-AI cells transiently using Lipofectamine 2000 (Invitrogen). WT1 expression was confirmed by Western blotting (Fig. 4B).
Up-regulation of $p 21^{\text {Wafl/Cipl }}$ expression by WT1 isoforms. Changes in endogenous $p 21^{\text {Wafl/Cipl }}$ expression were examined by real time RT-PCR (Fig. 5). $p 21^{\text {Wafl/Cipl }}$ mRNA levels were significantly up-regulated in four transfectants: WT1s $17 \mathrm{AA}^{+} /$ 
A

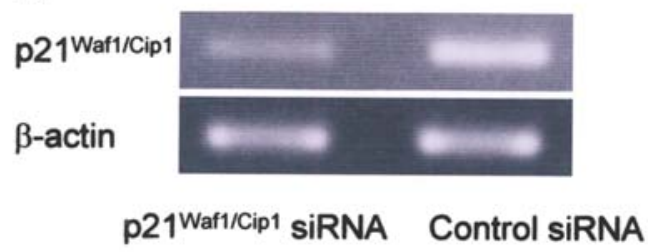

B

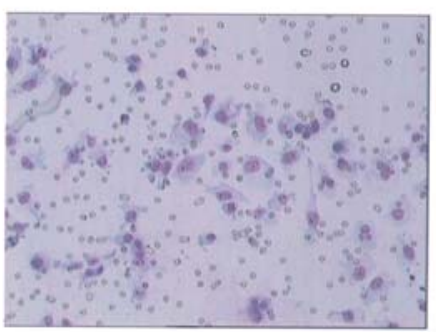

p21Waf1/Cip1 siRNA

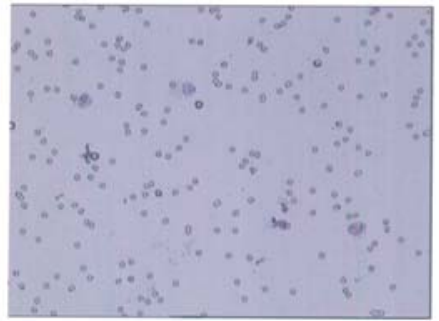

Control siRNA
C

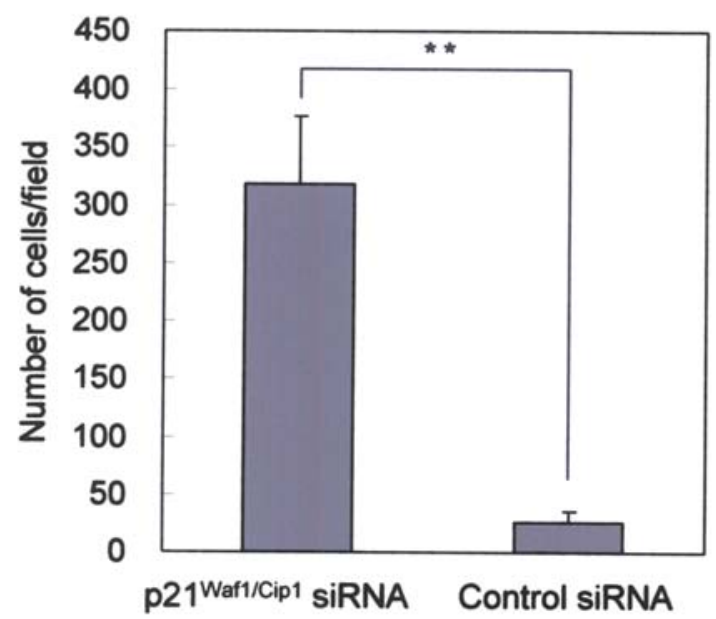

D

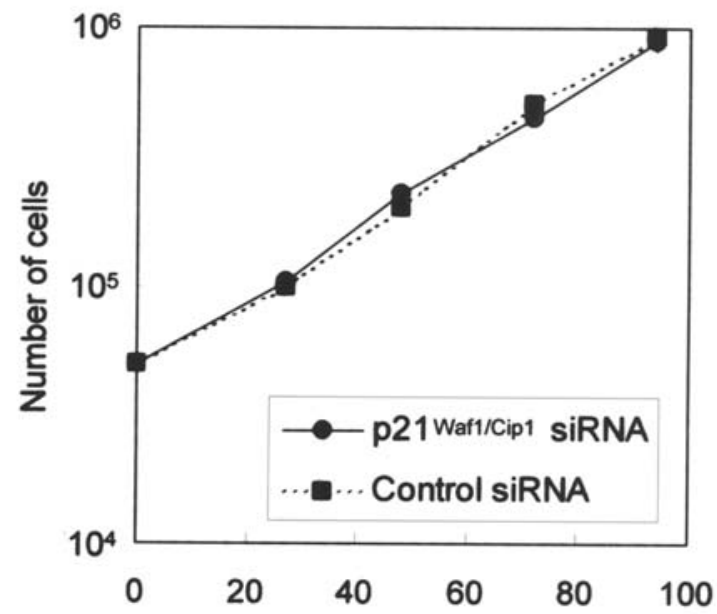

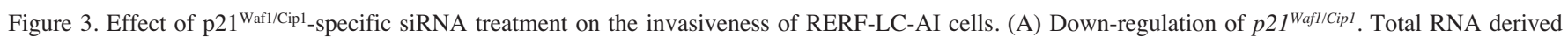
from RERF-LC-AI cells transfected with $p 21^{\text {Wafl/Cipl }}$-specific siRNA (p21 ${ }^{\text {Wafl/Cip1 }}$ siRNA) or negative control siRNA (control siRNA) were subjected to RT-PCR. (B) Invasion into Matrigel. Diff-Quick staining showed the invasiveness of cells transfected with $\mathrm{p} 21^{\text {Wafl/Cipl }}$ siRNA or control siRNA in an invasion assay. Cells were collected $24 \mathrm{~h}$ after transfection, dispersed in FBS-free DMEM, and added to the insert. After $22 \mathrm{~h}$, non-invading cells were removed from the upper filter surface and the filter was washed, fixed and stained. (C) Quantification of invasiveness. Compared with control siRNA-treated cells, p21 3 afl/Cip1 siRNA-treated cells showed significantly increased numbers of invading cells. ${ }^{* *} \mathrm{P}<0.01$. (D) Effect on RERF-LC-AI cell growth. Growth curves of cells transfected with $\mathrm{p} 21^{\text {Wafl/Cip1 }}$ siRNA or control siRNA showed no significant differences.

A

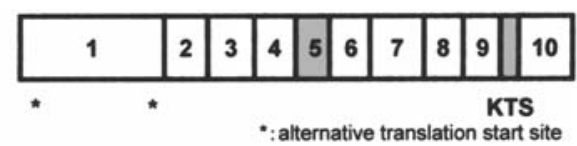

\begin{tabular}{|c|c|c|c|c|c|c|c|c|c|c|c|}
\hline (1) WT1s $17 A A+/ K T S+$ & & 1 & 2 & 3 & 4 & 5 & 6 & 7 & 8 & & 10 \\
\hline (2) WT1s 17AA+/KTS- & & 1 & 2 & 3 & 4 & 5 & 6 & 7 & 8 & 9 & 10 \\
\hline (3) WT 1s 17AA-/KTS+ & & 1 & 2 & 3 & 4 & 6 & 7 & 8 & \begin{tabular}{|l|l|}
9 & \\
\end{tabular} & 10 & \\
\hline (4) WT1s 17AA-/KTS- & & 11 & 2 & 3 & 4 & 6 & 7 & 8 & \begin{tabular}{|l|l}
9 & \\
\end{tabular} & 10 & \\
\hline (5) WT1 17AA+/KTS+ & 1 & & 2 & 3 & 4 & 5 & 6 & \begin{tabular}{l|l}
7 & $\varepsilon$ \\
\end{tabular} & 8 & & 10 \\
\hline (6) WT1 17AA+/KTS- & 1 & & 2 & 3 & 4 & 5 & 6 & 7 & 8 & 9 & 10 \\
\hline (7) WT1 17AA-/KTS+ & 1 & & 2 & 3 & 4 & 6 & 7 & 8 & 9 & $\frac{10}{7}$ & \\
\hline (8) WT1 17AA-/KTS- & 1 & & 2 & 3 & 4 & 6 & 7 & 8 & 9 & 10 & \\
\hline
\end{tabular}

B

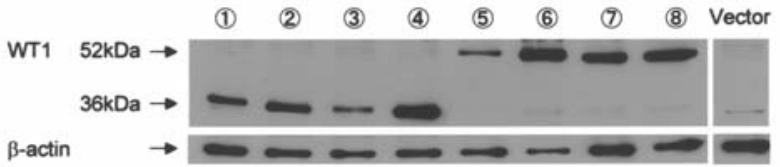

Figure 4. cDNA cloning of WT1 isoforms and protein expression. (A) Scheme used for the cloning of the WT1 isoforms. The eight WT1 isoforms were cloned into the pCMVFL3 expression vector. (B) WT1 isoform expression. RERF-LC-AI cells transiently transfected with each isoform WT1 expression vector or the empty expression vector pCMVFL3 (vector) were subjected to Western blot analysis.
KTS- $(\mathrm{P}<0.05)$, WT1s 17AA-/KTS- $\left(\mathrm{P}^{-}<0.05\right)$, WT1 17AA ${ }^{+}$ KTS- $^{-}(\mathrm{P}<0.05)$ and WT1s 17AA-/KTS- $(\mathrm{P}<0.05)$, compared with vector only-transfected cells, with no significant change in expression observed for the WT1s $17 \mathrm{AA}^{+} / \mathrm{KTS}^{+}$, WT1s 17.AA-/KTS ${ }^{+}$, WT1 $17 \mathrm{AA}^{+} / \mathrm{KTS}^{+}$, or $\mathrm{WT} 1 \mathrm{~s} 17 \mathrm{AA}^{-} / \mathrm{KTS}^{+}$ isoforms. The four isoforms that led to $p 21^{\text {Wafl/Cipl }}$ up-regulation commonly lacked the KTS domain situated at the end of exon 9, such that the alternative translation initiation sites and inclusion or exclusion of exon 5 did not appear to result in significant differences in expression.

Transactivation of the $p 21^{\text {Wafl/Cipl }}$ promoter by WT1 isoforms. The transcriptional activity of the WT1 isoforms was compared according to the ability to transactivate a reporter gene in RERF-LC-AI cells that had been transiently transfected with the WT1 isoforms (Fig. 6). The WT1s 17AA ${ }^{+} / \mathrm{KTS}^{-}(\mathrm{P}<0.01)$, WT1s 17AA-/KTS- $(\mathrm{P}<0.05)$, WT1 17AA ${ }^{+} / \mathrm{KTS}^{-}(\mathrm{P}<0.01)$ and WT1 17AA-/KTS- $(\mathrm{P}<0.05)$ isoforms were significantly more effective than the empty vector in transactivation of the $p 21^{\text {Wafl/Cipl }}$ promoter-driven reporter gene. In contrast, WT1s $17 \mathrm{AA}^{+} / \mathrm{KTS}^{+}, \mathrm{WT} 1 \mathrm{~s} 17 \mathrm{AA}^{-} / \mathrm{KTS}^{+}$, WT1 $17 \mathrm{AA}^{+} / \mathrm{KTS}^{+}$and WT1 $17 \mathrm{AA}^{-} / \mathrm{KTS}^{+}$is oforms exhibited no significant differences compared to the control. Therefore, only the -KTS 


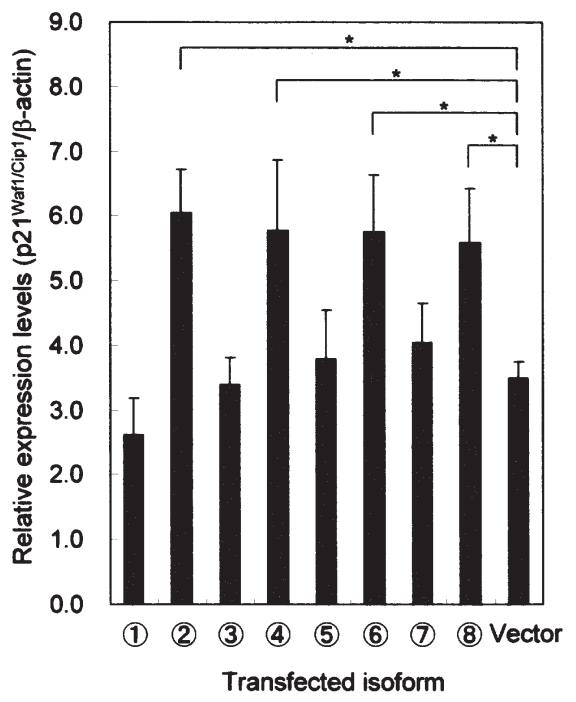

Figure 5. Effect of WT1 isoforms on endogenous $p 21^{\text {Wafl/Cipl } 1}$ expression. $p 21^{\text {Wafl/Cipl } 1}$ expression was quantified by real-time RT-PCR. $p 21^{\text {Wafl/Cipl } I} \mathrm{mRNA}$ level in non-treated RERF-LC-AI cells was defined as 1.0. $p 21^{\text {Wafl/CipI }}$ mRNA levels were significantly up-regulated by -KTS isoforms: (2) WT1s $17 \mathrm{AA}^{+} / \mathrm{KTS}^{-}$, (4) WT1s $17 \mathrm{AA}^{-} / \mathrm{KTS}^{-}$, (6) WT1 $17 \mathrm{AA}^{+} / \mathrm{KTS}^{-}$and (8) WT1s $17 \mathrm{AA}^{-} / \mathrm{KTS}^{-} .{ }^{*} \mathrm{P}<0.05$.

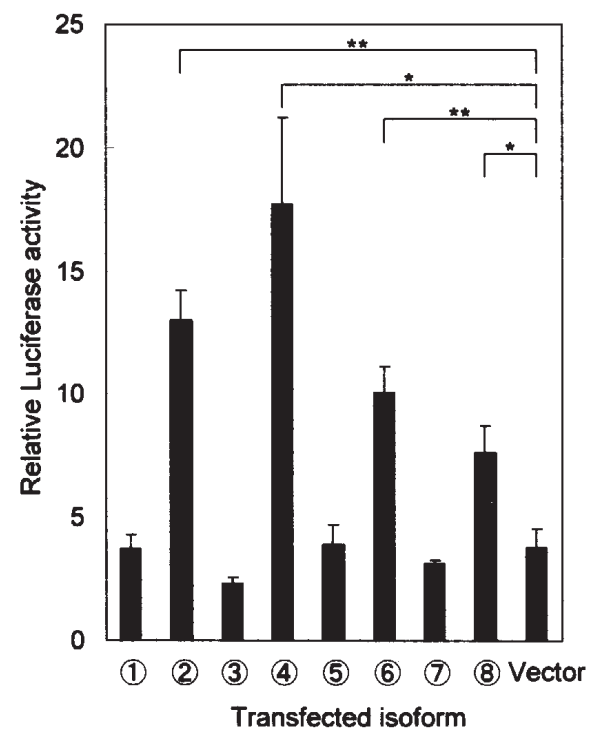

Figure 6. Transactivation of $p 21^{\text {Wafl/Cipl }}$ promoter by WT1 isofoms. RERFLC-AI cells were transfected with luciferase reporter constructs driven by the $p 21^{\text {Wafl/Cipl }}$ promoter and WT1 isoform expression constructs or the empty expression vector pCMVFL3 (vector). WT1 -KTS isoforms [(2)

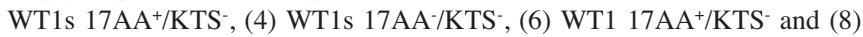
WT1 17 $\left.\mathrm{AA}^{-} / \mathrm{KTS}^{-}\right]$significantly transactivated reporter gene expression. ${ }^{*} \mathrm{P}<0.05,{ }^{* *} \mathrm{P}<0.01$.

isoforms significantly induced transactivation of the $p 21^{\text {Wafl/Cip } 1}$ promoter, while translation initiation site and presence or absence of exon 5 had no effect on transactivating activity.

\section{Discussion}

The WT1 gene was first isolated as a tumor suppressor gene responsible for Wilms' tumor (1). However, recent studies have shown that the wild-type WT1 gene is overexpressed in several types of leukemia (2-4) and solid tumors (5-14), and so may also have some oncogenic functions. The WT1 protein contains four zinc-finger domains and is involved in the transcriptional regulation of various genes (1). The presence of several WT1 isoforms has been reported and complicates explanations for its possible functions $(1,15)$.

The WT1 transcript is spliced alternatively at two sites: the 17AA site, which consists of exon 5, and the KTS site, located between zinc fingers 3 and 4 . Alternative splicing at these sites yields four isoforms $\left(17 \mathrm{AA}^{+} / \mathrm{KTS}^{+}, 17 \mathrm{AA}^{+} / \mathrm{KTS}^{-}\right.$, $17 \mathrm{AA}^{-} / \mathrm{KTS}^{+}$and $\left.17 \mathrm{AA}^{-} / \mathrm{KTS}^{-}\right)$. In addition to these WT1 isoforms, smaller WT1 isoforms have been described that are derived from internal translation initiation at the in-frame AUG 127 codon downstream of the initiator AUG. This generates a smaller isoform for each of the four isoforms described above (15). Lastly, a short transcript that lacks the $147 \mathrm{~N}$-terminal amino acids has also been reported (16). While these isoforms are expressed in various tumors, the function of each isoform in cancer cells remains unclear.

The WT1 gene is reported to be involved in the suppression of cancer cells. Transfection of four wild-type WT1 isoforms $\left(17 \mathrm{AA}^{+} / \mathrm{KTS}^{+}, 17 \mathrm{AA}^{+} / \mathrm{KTS}^{-}, 17 \mathrm{AA}^{-} / \mathrm{KTS}^{+}, 17 \mathrm{AA}^{-} / \mathrm{KTS}^{-}\right)$ suppressed the growth of RM1 cells derived from Wilms' tumor (17), while the $17 \mathrm{AA}^{-} / \mathrm{KTS}^{-}$isoform suppressed the growth of ras-transformed NIH3T3 cells in vitro and in vivo (18). However, there are several reports that WT1 can also function as an oncogene. For example, the growth of WT1expressing leukemia and solid cancer cells can be inhibited by treatment with WT1 antisense oligomers. Ambiguity in the function of WT1 is due at least in part to the lack of knowledge around its target genes as a regulator of transcription. Recently, Jomgeow et al demonstrated that the WT1 17AA-/KTS- isoform induced morphological changes, allowing cancer cells to acquire a more invasive phenotype in vitro, and that these phenotypic changes were induced through the altered expression of cytoskeletal regulatory proteins such as a-actinin 1, cofilin and gelsolin (19).

Examining the effect of constitutive expression of each of the WT1 isoforms in various cancer cell types can be used to find the target genes of WT1. In the present study, we carried out microarray analysis on human lung SCC cells treated with specific siRNA for WT1, and found that WT1 gene downregulation caused decreased expression of 23 genes, including the connective tissue growth factor gene (CTGF) (20) and the p53-regulated growth arrest and DNA damage-inducible gene (GADD45A) (21), which have been reported as metastasissuppressor genes. These results suggested that invasiveness in lung squamous cell carcinoma is controlled by WT1 through the regulation of several genes.

We focused on the $p 21^{\text {Wafl/Cipl }}$ gene for further analysis, as $p 21^{\text {Wafl/Cipl }}$ was found to be transactivated by the WT1 17AA ${ }^{+}$/ KTS- isoform (16) and thought to be involved in the metastasis of colorectal carcinomas (22). p $21^{\text {Wafl/Cip1 }}$ siRNA treatment caused no apparent change in cell growth, although $\mathrm{p} 21^{\text {Wafl/Cip1 }}$ is known as a cell cycle inhibitor. Sequence analysis revealed no mutations in any of the $p 21^{\text {Wafl/Cipl }}$ exons in the RERF-LC-AI cell line (data not shown). Weiss and Randour (23) showed no significant growth inhibition by treatment of $\mathrm{p} 53$-inactivated human SCC A431 cells with antisense p21 Waf1/Cip1 oligodeoxynucleotides. RERF-LC-AI cells are also p53-inactivated, 
as direct sequencing of p53 exon 4 indicated a $\mathrm{C} / \mathrm{T}$ mutation at codon 104 (data not shown) that results in the change of a glutamine to a stop codon. Thus, low-level $\mathrm{p} 21^{\text {Waf1/Cip1 }}$ may play a function in addition to the control of cell growth.

In this study, p $21^{\text {Waf } 1 / \text { Cip } 1}$ siRNA treatment enhanced invasion in vitro, consistent with the notion that $\mathrm{p} 21^{\mathrm{Waf} 1 / \mathrm{Cip} 1}$ inhibits invasion. Interaction between $\mathrm{p} 21^{\text {Waf } 1 / \text { Cip } 1}$ and Rho kinase (ROCK) is of interest as there is increasing evidence that Rho proteins are overexpressed in tumors (24-26), and overexpression of RhoC causes experimental metastasis in A375 melanoma cells (27). Rho signaling triggered by ROCK promotes cell motility through reorganization of actin filaments (28), and ROCK is thought to play an essential role in tumor cell invasion, since a specific ROCK inhibitor blocks invasive activity (29). However, cytoplasmic p $21^{\text {Waf1/Cip } 1}$ forms a complex with ROCK and inhibits its activity $(30,31)$, while Coqueret (32) suggested that cytoplasmic p21 $1^{\text {Waf } 1 / \text { Cip } 1}$ inhibits cell migration. Therefore, it is possible that RERF-LC-AI cell invasiveness is also inhibited by $\mathrm{p} 21^{\text {Wafl/Cip1-ROCK }}$ complexes.

In summary, down-regulated WT1 expression enhanced the invasiveness of lung SCC RERF-LC-AI cells. Downregulation of $p 21^{\text {Wafl/Cipl }}$, selected as a target gene of WT1 by DNA microarray analysis, also enhanced RERF-LC-AI cell invasiveness. Endogenous $p 21^{\text {Wafl } / \text { Cipl }}$ expression was upregulated in cells transfected with either of the four WT1 KTS isoforms. These four -KTS isoforms transactivated the p21 $1_{\text {Wafl/Cipl }}$ promoter-driven reporter gene expression. Thus, it appears that the WT1 -KTS isoforms suppress the invasiveness of lung SCC through the transactivation of $p 21^{\text {Wafl/Cipl }}$.

\section{References}

1. Scharnhorst V, van der Eb AJ and Jochemsen AG: WT1 proteins: functions in growth and differentiation. Gene 273: 141-161, 2001.

2. Inoue K, Sugiyama H, Ogawa H, et al: WT1 as a new prognostic factor and a new marker for the detection of minimal residual disease in acute leukemia. Blood 84: 3071-3079, 1994.

3. Miwa H, Beran M and Saunders GF: Expression of the Wilms' tumor gene (WT1) in human leukemias. Leukemia 6: 405-409, 1992.

4. Miyagi T, Ahuja H, Kubota T, Kubonishi I, Koeffler HP and Miyoshi I: Expression of the candidate Wilm's tumor gene, WT1, in human leukemia cells. Leukemia 7: 970-977, 1993.

5. Bruening W, Gros P, Sato T, et al: Analysis of the 11p13 Wilms' tumor suppressor gene (WT1) in ovarian tumors. Cancer Invest 11: 393-399, 1993.

6. Viel A, Giannini F, Capozzi E, et al: Molecular mechanisms possibly affecting WT1 function in human ovarian tumors. Int J Cancer 57: 515-521, 1994.

7. Miyoshi Y, Ando A, Egawa C, et al: High expression of Wilms' tumor suppressor gene predicts poor prognosis in breast cancer patients. Clin Cancer Res 8: 1167-1171, 2002.

8. Silberstein GB, Van Horn K, Strickland P, Roberts CT Jr and Daniel CW: Altered expression of the WT1 wilms tumor suppressor gene in human breast cancer. Proc Natl Acad Sci USA 94: 8132-8137, 1997.

9. Menssen HD, Bertelmann E, Bartelt S, et al: Wilms' tumor gene (WT1) expression in lung cancer, colon cancer and glioblastoma cell lines compared to freshly isolated tumor specimens. J Cancer Res Clin Oncol 126: 226-232, 2000.

10. Oji Y, Miyoshi S, Maeda H, et al: Overexpression of the Wilms tumor gene WT1 in de novo lung cancers. Int J Cancer 100: 297-303, 2002 .
11. Oji Y, Yano M, Nakano Y, et al: Overexpression of the Wilms tumor gene WT1 in esophageal cancer. Anticancer Res 24 3103-3108, 2004

12. Oji Y, Yamamoto H, Nomura M, et al: Overexpression of the Wilms' tumor gene WT1 in colorectal adenocarcinoma. Cancer Sci 94: 712-717, 2003

13. Oji Y, Inohara H, Nakazawa M, et al: Overexpression of the Wilms' tumor gene WT1 in head and neck squamous cell carcinoma. Cancer Sci 94: 523-529, 2003.

14. Srivastava A, Fuchs B, Zhang K, et al: High WT1 expression is associated with very poor survival of patients with osteogenic sarcoma metastasis. Clin Cancer Res 12: 4237-4243, 2006.

15. Scharnhorst V, Dekker P, van der Eb AJ and Jochemsen AG: Internal translation initiation generates novel WT1 protein isoforms with distinct biological properties. J Biol Chem 274: 23456-23462, 1999.

16. Hossain A, Nixon M, Kuo MT and Saunders GF: N-terminally truncated WT1 protein with oncogenic properties overexpressed in leukemia. J Biol Chem 281: 28122-28130, 2006.

17. Haber DA, Park S, Maheswaran S, et al: WT1-mediated growth suppression of Wilms tumor cells expressing a WT1 splicing variant. Science 262: 2057-2059, 1993.

18. Luo XN, Reddy JC, Yeyati PL, et al: The tumor suppressor gene WT1 inhibits ras-mediated transformation. Oncogene 11: 743-750, 1995.

19. Jomgeow T, Oji Y, Tsuji N, et al: Wilms' tumor gene WT1 $17 \mathrm{AA}(-) / \mathrm{KTS}(-)$ isoform induces morphological changes and promotes cell migration and invasion in vitro. Cancer Sci 97: 259-270, 2006.

20. Chang CC, Shih JY, Jeng YM, et al: Connective tissue growth factor and its role in lung adenocarcinoma invasion and metastasis. J Natl Cancer Inst 96: 364-375, 2004.

21. Hildesheim J, Belova GI, Tyner SD, Zhou X, Vardanian L and Fornace AJ Jr: Gadd45a regulates matrix metalloproteinases by suppressing DeltaNp63alpha and beta-catenin via p38 MAP kinase and APC complex activation. Oncogene 23: 1829-1837, 2004.

22. Mitomi H, Mori A, Kanazawa H, et al: Venous invasion and down-regulation of p21(WAF1/CIP1) are associated with metastasis in colorectal carcinomas. Hepatogastroenterology 52: 1421-1426, 2005.

23. Weiss RH and Randour CJ: The permissive effect of p21(Waf1/Cip1) on DNA synthesis is dependent on cell type: effect is absent in p53-inactive cells. Cell Signal 12: 413-418, 2000.

24. Fritz G, Just I and Kaina B: Rho GTPases are over-expressed in human tumors. Int J Cancer 81: 682-687, 1999.

25. Suwa H, Ohshio G, Imamura T, et al: Overexpression of the rhoC gene correlates with progression of ductal adenocarcinoma of the pancreas. Br J Cancer 77: 147-152, 1998.

26. van Golen KL, Davies S, Wu ZF, et al: A novel putative lowaffinity insulin-like growth factor-binding protein, LIBC (lost in inflammatory breast cancer), and RhoC GTPase correlate with the inflammatory breast cancer phenotype. Clin Cancer Res 5: 2511-2519, 1999.

27. Clark EA, Golub TR, Lander ES and Hynes RO: Genomic analysis of metastasis reveals an essential role for RhoC. Nature 406: 532-535, 2000.

28. Sahai E and Marshall CJ: Differing modes of tumour cell invasion have distinct requirements for Rho/ROCK signalling and extracellular proteolysis. Nat Cell Biol 5: 711-719, 2003.

29. Itoh K, Yoshioka K, Akedo H, Uehata M, Ishizaki T and Narumiya S: An essential part for Rho-associated kinase in the transcellular invasion of tumor cells. Nat Med 5: 221-225, 1999.

30. Lee S and Helfman DM: Cytoplasmic p21Cip1 is involved in Ras-induced inhibition of the ROCK/LIMK/cofilin pathway. J Biol Chem 279: 1885-1891, 2004

31. Tanaka H, Yamashita T, Asada M, Mizutani S, Yoshikawa H and Tohyama M: Cytoplasmic p21(Cip1/WAF1) regulates neurite remodeling by inhibiting Rho-kinase activity. J Cell Biol 158: 321-329, 2002.

32. Coqueret $\mathrm{O}$ : New roles for $\mathrm{p} 21$ and $\mathrm{p} 27$ cell-cycle inhibitors: a function for each cell compartment? Trends Cell Biol 13: 65-70, 2003. 